\title{
Leksykon teologii pastoralnej \\ red. R. Kamiński, W. Przygoda, M. Fiałkowski, Towarzystwo Naukowe KUL, Lublin 2006, s. 945
}

„Inicjatywa wydania Leksykonu teologii pastoralnej - jak zaznaczają jego Redaktorzy we Wstępie - jest ze wszech miar pożyteczna" (s. 6). W języku polskim nie wydano dotychczas żadnego leksykonu $\mathrm{z}$ teologii pastoralnej. Podobne leksykony wydano w językach niemieckim, włoskim i angielskim. Pierwszym wydanym w latach 1969-1972 był niemiecki Lexikon der Pastoraltheologie. Zawiera on 820 haseł, które dotyczą teologii pastoralnej w sensie ścisłym, ale także dyscyplin pokrewnych. Nie zawiera on biogramów. Kolejnym niemieckojęzycznym dziełem jest Lexikon der Pastoral z 2002 roku, w którym umieszczono 800 haseł. W porównaniu do wydania poprzedniego została uzupełniona literatura, sięgająca roku 2002. Godne uwagi są też włoskojęzyczne słowniki teologii pastoralnej (Dizionario di Pastorale della comunità cristiana, Assisi 1980) oraz encyklopedia duszpasterstwa (Enciclopedia di pastorale, Piemme 1992-1993, t. 1-4). $\mathrm{W}$ środowisku anglojęzycznym wart odnotowania jest słownik działalności duszpasterskiej (Dictionary of Pastoral Car and Counseling, Abingdon Press 1990), zawierający zagadnienia uniwersalne.

Ten krótki przegląd słowników wydanych w innych krajach prowadzi do przekonania, że istniała pilna potrzeba wydania takiej pozycji w Polsce. Była ona zgłaszana przez wykładowców tej dziedziny wiedzy w seminariach duchownych, pracowników naukowych akademickich i studentów oraz duszpasterzy. Nawet pobieżne przejrzenie haseł w Leksykonie prowadzi do przekonania, że może on być pomocą dla każdego Czytelnika, który interesuje się duszpasterstwem i teologią pastoralną. Należy zaznaczyć, że teologia pastoralna jest „naukową refleksją o codziennym wzrastaniu Kościoła, w mocy Ducha Świętego, w kontekście historii. [...] Czerpie ona $\mathrm{z}$ wiary zasady i kryteria działalności duszpasterskiej Kościoła w historii [...]. Wśród tych zasad i kryteriów szczególnie ważne miejsce zajmuje ewangeliczne rozeznanie sytuacji społeczno-kulturalnej i kościelnej, w której prowadzona jest działalność duszpasterska. Wiedzę, zdobytą dzięki studium teologii pastoralnej, należy wykorzystywać [...] w określonych formach posługi duszpasterskiej" (Jan Paweł II, Adhortacja apostolska Pastores dabo Vobis, nr 57).

We współczesnej teologii pastoralnej aspekty normatywny i praktyczny poznania naukowego stanowią zwartą całość. Nie można konstruować zasad, norm i modeli działalności eklezjalnej bez naukowej refleksji nad rzeczywistością pastoralną i podstawami jej oceny. Powyższe cechy składające się na specyfikę 
refleksji teologicznopastoralnej zostały wzięte pod uwagę przy opracowaniu haseł w Leksykonie teologii pastoralnej.

Omawiany Leksykon został opracowany przez zespół pracowników naukowych Specjalizacji Teologii Pastoralnej KUL pod kierownictwem ks. prof. dra hab. Ryszarda Kamińskicgo. Współredaktorami byli: ks. dr hab. Wiesław Przygoda i o. dr Marek Fiałkowski OFM Conv. W przygotowaniu Leksykonu brało udział także ponad stu przedstawicieli różnych ośrodków teologicznych w Polsce.

Leksykon obejmuje 406 haseł, z czego 257 haseł przedmiotowych z teologii pastoralnej i obszaru naukowego ściśle z nią związanego, które są zestawione w porządku alfabetycznym; 126 biogramów znanych teologów polskich i zagranicznych oraz 23 hasła odsyłaczowe, kierujące czytelnika do hasła właściwego.

Leksykon obejmuje całokształt zagadnień należących do teologii pastoralnej fundamentalnej i szczegółowej. Poszczególne hasła zostały ujęte syntetycznie i wszechstronnie, a niektóre także interdyscyplinarnie. Leksykon teologii pastoralnej umożliwia zrozumienie poszczególnych zagadnień, odkrywa powiązania ich $\mathrm{z}$ innymi zagadnieniami, przedstawia różne ujęcia i kierunki, wskazuje na możliwości zastosowania poszczególnych rozwiązań w praktycznej działalności Kościoła oraz wskazuje na obszary wymagające dalszych działań.

Leksykon może więc być przydatny dla duszpasterzy, katechetów oraz osób świeckich zaangażowanych w apostolstwo i życie Kościoła. W Polsce istnieje pilna potrzeba formacji pastoralnej osób świeckich. Wiedza zawarta w Leksykonie może być przydatna do ich formacji. Jest wiele zadań duszpasterskich Kościoła, które mogą być zrealizowane na odpowiednim poziomie dopiero wtedy, gdy będzie ścisła współpraca osób dobrze przygotowanych z kapłanami. Omawiane opracowanie stanowiące kompendium teologii pastoralnej może być przydatne dla pracowników mass-mediów. Często nieścisłości terminologiczne sprawiają wiele trudności tymże pracownikom w przekazie informacji z życia kościelnego.

Dużą wartością Leksykonu jest ujednolicenie terminologii teologicznopastoralnej na terenie języka polskiego. Autorzy opracowujący poszczególne hasła w swojej refleksji starali się poruszać po gruncie eklezjalnym i używać pojęć już wypracowanych wcześniej. W omawianej pozycji łatwo zauważa się, że jest w niej miejsce dla intelektualizmu katolickiego, ale jest też obecna pobożność ludowa.

Znaczące jest również umieszczenie problematyki małżeństwa i rodziny w Leksykonie teologii pastoralnej. Na 280 haseł tematycznych 18 jest związanych ściśle z rodziną i Duszpasterstwem Rodzin. Liczby wskazują, że ten problem został mocno zaakcentowany w prezentowanym dziele. Wiele miejsca poświęcono poszczególnym etapom przygotowania chrześcijan do małżeństwa, co stanowi ważne zadanie w duszpasterstwie. 
Należy podkreślić duże znaczenie biogramów w Leksykonie. Struktura haseł osobowych zawiera pięć elementów. Pierwszy to nazwisko i imię, lata życia, stopień święceń, ewentualna profesja zakonna, tytuł naukowy. Drugi element dotyczy duchownych i opisuje przebieg pracy duszpasterskiej. Na trzecim etapie wymienione są odbyte studia, tytuły prac naukowych, podejmowane wykłady i opisana jest działalność naukowa. Następnie ukazane są zainteresowania badawcze danej osoby i wpływ na rozwój teologii pastoralnej. $\mathrm{Na}$ końcu wymienione są publikacje prezentowanej osoby, wykaz literatury, księgi jubileuszowe im poświęcone, dane z witryn internetowych. Przyjęto, że maksymalnie prezentowanych jest nie więcej jak 15 pozycji. W opracowanych biogramach przedstawiono osoby żyjące od wieku XIX po czas współczesny. Ich prezentacja $\mathrm{w}$ Leksykonie pozwala prześledzić dzieje teologii pastoralnej na przestrzeni kolejnych lat.

Niewątpliwym blaskiem prezentowanego dzieła jest jego ścisły związek ze specyfiką polską, reprezentowane są w nim wszystkie środowiska pastoralistów, hasła opracowane są według stałego schematu (odbiegają od niego tylko biogramy). Cieniem natomiast Leksykonu może być niewielka stosunkowo liczba haseł, która związana być może była $\mathrm{z}$ ograniczoną możliwością pozyskania środków oraz za skromna kampania reklamująca. Uważam, że dzieło to powinno być bardziej wyeksponowane i rozreklamowane, gdyż stanowi duże osiągnięcie naukowe.

Wszystkim, którzy przyczynili się do powstania pierwszego polskiego Leksykonu teologii pastoralnej, należą się słowa uznania i wdzięczności za podjęty trud i owocną konsekwencję w jego realizacji.

Ks. Adam Skreczko Uniwersytet $w$ Bialymstoku 